\title{
New substrate containing agroindustrial carnauba residue for production of papaya under foliar fertilization
}

\author{
Francisca G. Albano ${ }^{1}$, Ítalo H. L. Cavalcante ${ }^{2}$, Jailson S. Machado ${ }^{3}$, \\ Claudivan F. de Lacerda ${ }^{4}$, Esdras R. da Silva ${ }^{5}$ \& Humberto G. de Sousa ${ }^{4}$ \\ ${ }^{1}$ Universidade Federal do Ceará/Centro de Ciências Agrárias/Departamento de Fitotecnia. Fortaleza, CE. E-mail: gislene.fga@gmail.com (Corresponding author) \\ ${ }^{2}$ Universidade Federal do Vale do São Francisco/Centro de Ciências Agrárias/Curso de Engenharia Agronômica. Petrolina, PE. E-mail: italo.cavalcante@univasf.edu.br \\ ${ }^{3}$ Universidade Federal do Piauí/Campus Professora Cinobelina Elvas. Bom Jesus, PI. E-mail: jailson.mapas@gmail.com \\ ${ }^{4}$ Universidade Federal do Ceará/Centro de Ciências Agrárias/Departamento de Engenharia Agrícola. Fortaleza, CE. E-mail: cfeitosa@ufc.br; \\ humbertosousa71@hotmail.com \\ ${ }^{5}$ Universidade Federal do Ceará/Centro de Ciências Agrárias/Departamento de Solos e Nutrição de Plantas. Fortaleza, CE. E-mail: esdrasyave@gmail.com
}

\section{Key words:}

Carica papaya

quality seedlings

mineral nutrition

\begin{abstract}
A B S T R A C T
The use of organic waste in the composition of substrates for seedlings constitutes an alternative to the recycling of these materials. Thus, an experiment was conducted with the objective to evaluate the production of 'Formosa' papaya seedlings in substrate containing carnauba wax residue, under foliar fertilization. The experimental design was completely randomized with five replicates, with treatments distributed in a $5 \times 2$ factorial scheme, corresponding to five materials used as substrates, in the presence and absence of foliar fertilization. The materials used were: earthworm humus, carnauba residue + fresh rice husk; carnauba residue in powder; carnauba residue semi-decomposed and mixture of carnauba residues: carnauba residue + fresh rice husk + carnauba residue semi-decomposed + carnauba residue in powder, at the proportion 1:1:1. The agroindustrial residue of carnauba wax semi-decomposed can be used as substrates in the production of 'Formosa' papaya seedlings. The foliar fertilization increases the quality of papaya seedlings, leading to increment in leaf area, root volume and sulfur content in the leaves, thus becoming a necessary practice.
\end{abstract}

\section{Palavras-chave:}

Carica papaya qualidade de mudas nutrição mineral

\section{Substrato contendo resíduo agroindustrial de carnauba para produção de mudas de mamoeiro sob adubação foliar}

\section{R E S U M O}

O uso de resíduos orgânicos na composição de substratos para mudas constitui uma alternativa à reciclagem desses materiais. Neste sentido, um experimento foi realizado com o objetivo de avaliar a produção de mudas de mamoeiro formosa produzidas em substrato contendo resíduo de cera de carnauba com adubação foliar. Adotou-se delineamento experimental inteiramente casualizado com cinco repetições, com tratamentos distribuídos em esquema fatorial $5 \times 2$, referentes a cinco materiais utilizados como substratos na presença e ausência de adubação foliar. Os materiais usados foram: húmus de minhoca; resíduo de carnauba + casca de arroz in natura; resíduo de carnauba em pó; resíduo de carnauba semidecomposto e mistura de resíduos de carnauba: resíduo de carnauba + casca de arroz in natura + resíduo de carnauba semidecomposto + resíduo de carnauba em pó (1:1:1). O resíduo agroindustrial da cera de carnauba semidecomposto (RCSD) pode ser usado como substrato na produção de mudas de mamoeiro formosa. A adubação foliar incrementa a qualidade de mudas de mamoeiro, propiciando expansão na área foliar, no volume radicular e no teor foliar de enxofre tornando-se, portanto, uma prática necessária. 


\section{INTRODUCTION}

Papaya (Carica papaya L.) is a herbaceous plant of tropical and subtropical climates, well adapted to the Brazilian territory, where it has great economic importance among fruit crops, especially in the Northeast region, with annual production of 250,954 t (IBGE, 2012).

Papaya orchards have been installed adopting seedlings propagated through seeds, for commercial purposes, using commercial substrates with high cost and without the use of regional materials with potential, a fact that stimulates the conduction of research projects involving inputs of wide availability, reduced costs and efficient in the seedling production process (Matos et al., 2012; 2016; Albano et al., 2014).

The use of agroindustrial residues as components of substrates to produce seedlings minimizes the disposal in the open air or in landfills and, consequently, their accumulation in the environment (Silva Júnior et al., 2014), but it requires studies especially on the quality of the formed seedling. One of the residues with potential to be used as substrate component is the residue of carnauba (Copernicia prunifera Mill.), produced from the agroindustrial process of carnauba wax extraction, which has, according to the scientific literature, promising results for crops such as pineapple (Weber et al., 2003), acerola (Lima et al., 2006), heliconias (Cavalcante et al., 2011) and tomato (Silva Júnior et al., 2014).

One of the evaluation methods used in the analysis of seedling quality is the nutritional status, aiming at the fertilization management and, consequently, maximum efficiency of absorption, translocation and redistribution through the determination of critical and adequate levels for the species (Falcão Neto et al., 2014). In the production of fruit crops, the use of foliar fertilization has been adopted as an important tool in the nutritional management, including by certified nursery owners, to obtain higher-quality seedlings. However, there are not many data in the literature related to the effects of foliar fertilization on the production of fruit crop seedlings associated with substrate composition and its effects on biometry, quality and nutritional status of the seedlings, especially when the substrate receives agroindustrial residues, particularly from the carnauba agroindustry.

Therefore, this study aimed to evaluate the production of 'Formosa' papaya seedlings in substrate containing carnauba wax residue and under foliar fertilization.

\section{Material ANd Methods}

The experiment was carried out from September to November 2014, in a protected environment, at the Federal
University of Ceará (UFC), Fortaleza, CE, Brazil. During the experiment, mean temperature of $27.5^{\circ} \mathrm{C}$ and mean relative air humidity of $72.5 \%$ were recorded using a digital thermohygrometer (Instrutemp', Brasil).

The experimental design was completely randomized with treatments distributed in a $5 \times 2$ factorial scheme, corresponding to five substrate compositions based on carnauba residue. The materials used as substrate were: Earthworm humus (EH) (commercial substrate); 2) carnauba residue + fresh rice husk $(\mathrm{FRH})$; 3) carnauba residue in powder (CRP); 4) carnauba residue semi-decomposed (CRSD) and 5) mixture of carnauba residues: carnauba residue + fresh rice husk + carnauba residue semi-decomposed + carnauba residue in powder (MCR), 1:1:1, in the presence or absence of foliar fertilization. Five replicates were used with five seedlings per plot, totaling 250 seedlings.

Foliar fertilization was weekly performed using the fertilizer Niphocan ${ }^{\circ}$ (composition: 10, 8, 8, 0.5, 1, 2, 1, 0.5, $0.1,0.1,0.2$ and $0.5 \%$ of $\mathrm{N}, \mathrm{P}_{2} \mathrm{O}_{5}, \mathrm{~K} 2 \mathrm{O}, \mathrm{Mg}, \mathrm{Ca}, \mathrm{S}, \mathrm{Zn}, \mathrm{B}, \mathrm{Fe}$, $\mathrm{Mo}, \mathrm{Cu}$ and $\mathrm{Mn}$, respectively) at the concentration of $1 \mathrm{~mL} \mathrm{~L}^{-1}$, according to the recommendations of the manufacturer, only in the treatments with foliar fertilization (WFF), totaling 6 applications.

For the formation of the seedlings, plastic bags $(16 \times 26 \mathrm{~cm})$ were used as containers, filled with standardized substrates in a volume of approximately $2.5 \mathrm{~L}$. Two seeds of 'Formosa' papaya (cv. Tainung 01) were planted in each container and thinning was performed 15 days after emergence of the seedlings, leaving only the most vigorous.

For the determination of the necessity of water replacement, the plastic bags filled with the respective substrates were saturated with water up to field capacity and again weighed to record the reference mass. The bags were daily weighed on a scale (Balmak Economic ${ }^{\circ}$ ) and the amount equivalent to $70 \%$ of evaporation was replaced.

Chemical (Table 1) and physical (Table 2) characterization of each substrate was performed at the Laboratory of Soil Sciences of the Federal University of Ceará, respectively following the methodologies described by MAPA (2007) and Schmitz et al. (2002).

For the determination of the effects of the respective treatments on the formation of 'Formosa' papaya seedlings, the following variables were determined at the end of the experiment, 60 days after sowing (DAS): i) seedling height (cm); ii) stem diameter ( $\mathrm{mm})$; iii) chlorophyll (index), according to the recommendations of El-Hendawy et al. (2005).

The seedlings were removed from the substrates, washed in running water and taken to the Laboratory of Agricultural

Table 1. Values of $\mathrm{pH}$, electrical conductivity $(\mathrm{EC})$ and total contents of nitrogen $(\mathrm{N})$, phosphorus $(\mathrm{P})$, potassium $(\mathrm{K})$, calcium $(\mathrm{Ca})$ and magnesium $(\mathrm{Mg})$ of the materials used as substrates

\begin{tabular}{|c|c|c|c|c|c|c|c|c|}
\hline \multirow{2}{*}{ Substrates } & \multirow{2}{*}{$\mathrm{pH}$} & \multirow{2}{*}{$\begin{array}{c}\mathrm{EC} \\
\mathrm{dS} \mathrm{m}^{-1}\end{array}$} & $\mathbf{N}$ & $\mathbf{P}$ & $\mathrm{K}$ & $\mathrm{Ca}$ & $\mathrm{Mg}$ & $S$ \\
\hline & & & \multicolumn{2}{|c|}{$\mathrm{g} \mathrm{kg}^{-1}$} & \multicolumn{4}{|c|}{$\mathrm{cmol}_{\mathrm{c}} \mathrm{kg}^{-1}$} \\
\hline $\mathrm{EH}$ & 6.8 & 4.62 & 14.56 & 0.002 & 7.71 & 28.0 & 2.8 & 3.30 \\
\hline $\mathrm{CRRH}$ & 5.3 & 6.84 & 24.56 & 0.097 & 17.36 & 8.0 & 15.5 & 5.34 \\
\hline CRP & 5.6 & 6.53 & 30.30 & 0.089 & 20.07 & 6.5 & 17.0 & 2.55 \\
\hline CRSD & 5.6 & 5.90 & 26.54 & 0.055 & 23.93 & 6.0 & 16.8 & 3.52 \\
\hline MCR & 5.5 & 5.58 & 21.50 & 0.058 & 24.45 & 8.5 & 13.5 & 3.75 \\
\hline
\end{tabular}

EH - Earthworm humus (commercial substrate); CRRH - Carnauba residue + rice husk; CRP - Carnauba residue in powder; CRSD - Carnauba residue semi-decomposed; MCR - Mixture of carnauba residue (carnauba residue with rice husk + carnauba residue semi-decomposed + carnauba residue in powder) 
Table 2. Soil bulk density (DS), soil particle density (DP), moisture [field capacity - $0.033 \mathrm{MPa}(\mathrm{FC})$, permanent wilting point - 1.5 MPa (PWP) and available water (AW)] and porosity $(\mathrm{P})$, of the materials used as substrates

\begin{tabular}{ccccccc}
\hline \multirow{3}{*}{ Substrates } & \multicolumn{2}{c}{$\begin{array}{c}\text { Density } \\
\left(\mathbf{k g ~ d m}^{-3}\right)\end{array}$} & \multicolumn{5}{c}{$\begin{array}{c}\text { Moisture } \\
\left(\mathbf{g ~ 1 0 0 g}^{-1}\right)\end{array}$} \\
\cline { 2 - 3 } \cline { 5 - 6 } & DS & DP & FC & PWP & AW & \\
EH & 0.64 & 1.18 & 83.83 & 72.25 & 11.58 & 45.76 \\
CRRH & 0.51 & 1.71 & 84.39 & 65.28 & 19.11 & 70.18 \\
CRP & 0.43 & 3.27 & 114.29 & 83.02 & 31.27 & 86.85 \\
CRSD & 0.40 & 4.08 & 101.01 & 78.94 & 22.07 & 90.44 \\
MCR & 0.45 & 2.02 & 81.07 & 76.25 & 4.82 & 77.72 \\
\hline
\end{tabular}

EH - Earthworm humus (commercial substrate); CRRH - Carnauba residue + rice husk; CRP - Carnauba residue in powder; CRSD - Carnauba residue semi-decomposed; MCR - Mixture of carnauba residue (carnauba residue with rice husk + carnauba residue semi-decomposed + carnauba residue in powder): DS - Soil bulk density; DP - Soil particle density; FC - Field capacity; PWP - Permanent wilting point; AW - Available water; P - Porosity

Meteorology of the Agricultural Engineering Department of the UFC, where the following variables were evaluated: i) leaf area $\left(\mathrm{cm}^{2}\right)$; ii) root length $(\mathrm{cm})$; iii) root volume $\left(\mathrm{cm}^{3}\right)$; and iv) shoot and root dry matter (g). In addition, the Dickson quality index (DQI) was determined using the Eq. 1 (Dickson et al., 1960):

$$
\mathrm{DQI}=\frac{\mathrm{TDM}}{\mathrm{PH} / \mathrm{SD}^{+} \mathrm{SDM} / \mathrm{RDM}}
$$

where:

$$
\begin{aligned}
& \text { TDM - total dry matter, g; } \\
& \text { PH - plant height, g; } \\
& \text { SD - stem diameter, mm; } \\
& \text { SDM - shoot dry matter, g; and, } \\
& \text { RDM - root dry matter, g. }
\end{aligned}
$$

The contents of macronutrients (N, P, K, Ca, Mg and S) in the shoots $\left(\mathrm{g} \mathrm{kg}^{-1}\right)$ were also determined using the methodology described by Malavolta et al. (1997).

The data were subjected to analysis of variance by $\mathrm{F}$ test, for the diagnosis of significant effect, and the treatments were compared by Tukey test to evaluate the significant difference using the software Assistat.

\section{Results AND Discussion}

As observed in Table 3, there was isolated effect of the different substrates on plant height, stem diameter, leaf chlorophyll index, leaf area, shoot dry matter, root dry matter, root length and root volume $(\mathrm{p}<0.01)$, while the foliar fertilization promoted significant difference only for root volume $(\mathrm{p}<0.01)$. For the interaction between the substrates and foliar fertilization, the effect was significant only for leaf area $(\mathrm{p}<0.05)$ and root volume $(\mathrm{p}<0.01)$.

For plant height (Table 3 ), the highest means occurred in the carnauba residue semi-decomposed (CRSD) and earthworm humus $(\mathrm{EH})$, which did not differ statistically. The substrate CRSD showed superiority of 400.37 and $318.25 \%$ in relation to the carnauba residue with rice husk (CRRH) and mixture of carnauba residue (carnauba residue with rice husk + carnauba residue semi-decomposed + carnauba residue in powder) (MCR), respectively. According to Costa et al. (2010), the minimum height of $20 \mathrm{~cm}$ is considered as ideal for papaya transplantation and the treatments $\mathrm{CRSD}$ and $\mathrm{EH}$ reached this mean between 40 and 45 days after sowing, which promotes to the nursery owner a faster seedling production cycle. In comparison to the literature, Albano et al. (2014) report that the substrate with decomposed buriti stem, at the proportion of $20 \%$, led to maximum height of $35 \mathrm{~cm}$ and Silva et al. (2013), studying the production of 'Formosa' papaya seedlings under the effect of thermo-reflective screen and substrates, observed that the substrate with $80 \%$ of Organosuper and $20 \%$ of soil led to highest seedling height $(23.7 \mathrm{~cm})$ at 96 days after sowing. These results are much lower than those found in the present study.

Stem diameter (Table 3) followed the same trend of plant height, i.e., the best results were observed for CRSD and EH, with superiority of approximately $571.94 \%$ in comparison to

\begin{tabular}{|c|c|c|c|c|c|c|c|c|c|}
\hline Source of variation & PH & SD & CLO & $\overline{L A}$ & $\overline{R L}$ & RV & SDM & RDM & DQI \\
\hline S & $50.26^{\star *}$ & $90.23^{* *}$ & $44.95^{\star \star}$ & $1158.05^{\star *}$ & $14.28^{\star *}$ & $291.17^{\star \star}$ & $942.26^{* *}$ & $187.24^{* \star}$ & 202.47 \\
\hline $\mathrm{FF}$ & $3.69^{\text {ns }}$ & $0.64^{\mathrm{ns}}$ & $0.99^{\text {ns }}$ & $0.55^{\mathrm{ns}}$ & $0.37^{\text {ns }}$ & $11.28^{* *}$ & $1.44^{\mathrm{ns}}$ & $0.56^{\mathrm{ns}}$ & 0.05 \\
\hline SxFF & $1.16^{\mathrm{ns}}$ & $0.56^{\mathrm{ns}}$ & $1.47^{\text {ns }}$ & $2.60^{*}$ & $0.53^{\text {ns }}$ & $7.11^{\star \star}$ & $0.33^{\text {ns }}$ & $0.43^{\text {ns }}$ & $0.55^{\text {ns }}$ \\
\hline CV (\%) & 29.01 & 27.45 & 11.23 & 10.12 & 20.63 & 17.67 & 2.45 & 20.55 & 15.05 \\
\hline & \multicolumn{8}{|c|}{ Mean } & \\
\hline & $\overline{\mathrm{cm}}$ & $\overline{\mathrm{mm}}$ & (index) & $\mathrm{cm}^{2}$ & $\mathrm{~cm}$ & $\mathrm{~cm}^{3}$ & \multicolumn{2}{|c|}{ g } & \\
\hline EH & $38.47 a$ & $11.24 \mathrm{a}$ & $46.55 \mathrm{a}$ & $8439.41 b$ & $29.95 \mathrm{a}$ & $300.00 \mathrm{~b}$ & $103.92 \mathrm{a}$ & $12.15 \mathrm{a}$ & $9.96 \mathrm{~b}$ \\
\hline CRRH & $10.54 \mathrm{~b}$ & $2.31 \mathrm{~b}$ & $31.02 \mathrm{~b}$ & $958.05 \mathrm{C}$ & $22.00 \mathrm{~b}$ & $42.50 \mathrm{C}$ & $22.71 \mathrm{c}$ & $3.25 b$ & $2.25 d$ \\
\hline CRP & $15.67 \mathrm{~b}$ & $2.21 \mathrm{~b}$ & $32.31 \mathrm{~b}$ & 781.96 c & $20.38 \mathrm{~b}$ & $52.50 \mathrm{c}$ & $35.84 \mathrm{~b}$ & 3.57 b & $2.30 \mathrm{~d}$ \\
\hline CRSD & $42.20 \mathrm{a}$ & $12.64 \mathrm{a}$ & $49.87 \mathrm{a}$ & $10919.80 \mathrm{a}$ & $33.66 \mathrm{a}$ & $422.00 \mathrm{a}$ & $110.23 \mathrm{a}$ & $15.26 \mathrm{a}$ & $11.88 \mathrm{a}$ \\
\hline MCR & $13.26 b$ & $3.05 b$ & $31.80 \mathrm{~b}$ & $1171.08 \mathrm{C}$ & $20.01 b$ & $82.50 \mathrm{C}$ & 40.42 b & $6.12 b$ & $4.25 \mathrm{C}$ \\
\hline LSD & 8.57 & 2.20 & 5.49 & 576.03 & 6.64 & 40.60 & 5.47 & 3.16 & 1.34 \\
\hline WoFF & $21.03 \mathrm{a}$ & $6.09 \mathrm{a}$ & $37.70 \mathrm{a}$ & $4406.44 \mathrm{a}$ & $24.75 \mathrm{a}$ & $164.80 \mathrm{~b}$ & $62.67 \mathrm{a}$ & $11.80 \mathrm{a}$ & $8.45 a$ \\
\hline WFF & $24.64 \mathrm{a}$ & $6.49 \mathrm{a}$ & $38.92 \mathrm{a}$ & $4501.68 \mathrm{a}$ & $25.65 \mathrm{a}$ & $195.00 \mathrm{a}$ & $64.41 \mathrm{a}$ & $12.33 \mathrm{a}$ & $8.35 \mathrm{a}$ \\
\hline LSD & 3.79 & 0.98 & 2.46 & 257.90 & 2.97 & 18.17 & 2.92 & 1.41 & 0.96 \\
\hline
\end{tabular}
the third highest mean (carnauba residue in powder - CRP), demonstrating that the greater stem diameter can be related

Table 3. Summary ANOVA and observed means of plant height (PH), stem diameter (SD), leaf chlorophyll index (CLO), leaf area (LA), shoot dry matter (SDM), root dry matter (RDM), root length (RL), root volume (RV) and Dickson quality index (DQI) of 'Formosa' papaya seedlings as a function of substrates and foliar fertilization

LSD - Least significant difference; CV - Coefficient of variation; S - Substrates; EH - Earthworm humus (commercial substrate); CRRH - Carnauba residue + rice husk; CRP - Carnauba residue in powder; CRSD - Carnauba residue semi-decomposed; MCR - Mixture of carnauba residue (carnauba residue with rice husk + carnauba residue semi-decomposed + carnauba residue in powder); FF - Foliar fertilization; WoFF - Without foliar fertilization; WFF - With foliar fertilization; ns: not significant; *Significant at 0.05 probability level; ${ }^{\star \star}$ Significant at 0.01 probability level; means followed by the same letter in each column do not differ by Tukey test at 0.05 probability level 
to plant height, due to the accumulation of photoassimilates, which are very important to the metabolic process, helping in the central role of the reactions involving ATP (Pessarakli, 2014), which possibly occurred in the present study.

The mean results of stem diameter observed in the present study are higher than those reported by Saraiva et al. (2011), who tested the production of papaya seedlings under doses of phosphate fertilization.

For the leaf chlorophyll index (Table 3), there was no difference between CRSD and EH, which showed means approximately $160.76 \%$ higher in comparison to the other substrates. The chlorophyll indices are used to estimate the photosynthetic potential of the plants with positive proportionality due to its direct link with the absorption and transfer of light energy (Pessarakli, 2014). Thus, this is one of the hypotheses for the seedlings formed in the substrates CRSD and $\mathrm{EH}$ to show higher photosynthetic rates and, consequently, greater plant height, stem diameter and chlorophyll index.

As observed in Table 3, the best result of leaf area was obtained in CRSD, followed by the substrate containing EH. These results are higher than those reported by Araújo et al. (2010), who used organic substrates in the production of 'Formosa' papaya seedlings and claimed that the increase in the number of leaves occurs because the leaf area reflects in higher vegetal production, since it is related to the photosynthetic capacity of the plants (Pessarakli, 2014), i.e., it led to higher light assimilation, photosynthesis, dry matter accumulation and height of papaya seedlings.

Shoot and root dry matters (Table 3 ) followed the same trend. In CRSD and EH treatments these variables were approximately $470 \%$ higher compared with plants cultivated in the substrates CRRH, CRP and MCR. These results agree with those of Silva Júnior et al. (2014), who studied alternative substrates and foliar fertilization in the production of tomato seedlings and found the best results with residue + rice husk and semi-decomposed residue.

The substrates CRSD and EH also showed the best values of root length and root volume (Table 3 ), which were 168.2 and $992.94 \%$ higher, respectively, in comparison to the lowest means observed in MCR. These results contradict the studies of Steffen et al. (2011), who claimed that the root development is antagonistic to shoot development, which can be influenced by the nutritional composition of the substrate or the hormonal status of the plant. Quantitatively, Menegazzo et al. (2011) reported results of root length $(34.99 \mathrm{~cm})$ similar to those of the present study.

Regarding the Dickson quality index (DQI) (Table 3), the CRSD promoted the highest means, i.e., better quality pattern, since, according to Melo Júnior et al. (2014), the higher the DQI, the better the quality of the seedling. These results were higher than those reported by Costa et al. (2010), Almeida et al. (2011), Silva et al. (2013) and Melo Júnior et al. (2014), who also evaluated DQI in the production of papaya seedlings.

In general, the superiority of CRSD and $\mathrm{EH}$ regarding the phytotechnical variables are related to the respective physical and chemical characteristics of these substrates. According to Kämpf (2000), the $\mathrm{pH}$ value can vary in organic-based substrates and the ideal range is between 5.2 and 5.5. Values within this range or very close were obtained in the present study, except in the EH (Table 1). In addition, according to Ayers \& Westcot (1999) the papaya crop is considered as moderately tolerant to soil salinity. Thus, it tolerates electrical conductivity levels between 3 and 6 $\mathrm{dS} \mathrm{m}^{-1}$ without growth inhibition, and its productive capacity indicates that the development of the seedlings in the present study was not negatively influenced by the electrical conductivity found in the studied substrates.

For the substrates that showed the best results of the phytotechnical variables (EH and CRSD) (Table 2), the CRSD has double the pores (better aeration) and promotes double the amount of available water to the plants, in comparison to $\mathrm{EH}$. Only the available water observed in the substrate CRSD is in agreement with the range considered as adequate by Boodt \& Verdonck (1972), which suggests that this material can guarantee high water availability to plants and constitute a difference for the superiority in relation to the others regarding the phytotechnical variables of the 'Formosa' papaya seedlings. On the other hand, Verdonck \& Gabriels (1988) defined that the ideal value of porosity for vegetable substrates is $0.85 \mathrm{~m}^{3} \mathrm{~m}^{-3}$, which, among the studied substrates, does not apply only to EH (Table 2).

Foliar fertilization promoted significant increment in leaf area (Figure 1A) and in root volume (Figure 1B), equal to 8.02 and $25.97 \%$, respectively, as also observed by Yamanishi et al. (2004), who studied the effect of different substrates and two forms of fertilization on the production of papaya seedlings and obtained positive results for the development of the seedlings.
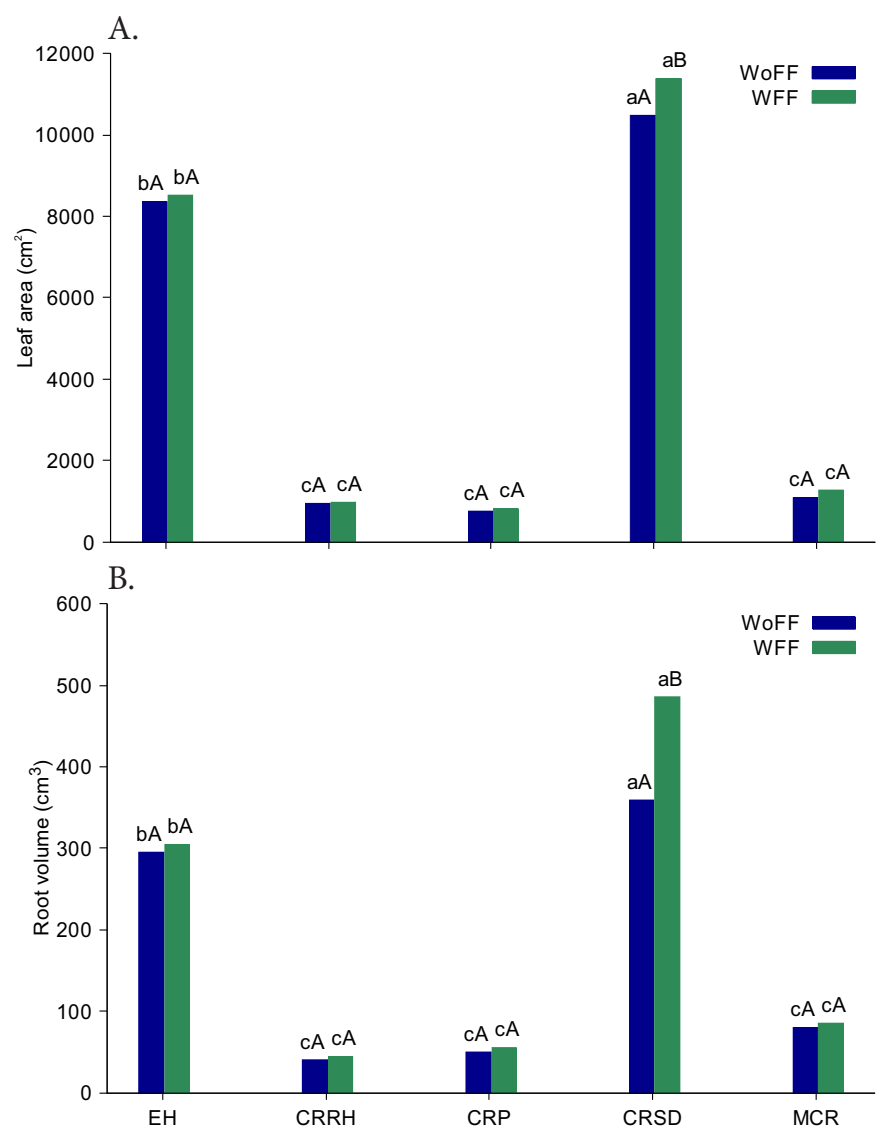

Bars with the same lower and uppercase letters do not differ with respect to substrate composition and foliar fertilization, respectively, by Tukey test at 0.05 probability levels. $\mathrm{EH}$ - Earthworm humus (commercial substrate); CRRH - Carnauba residue + rice husk; CRP Carnauba residue in powder; CRSD - Carnauba residue semi-decomposed; MCR - Mixture of carnauba residue (carnauba residue with rice husk + carnauba residue semi-decomposed + carnauba residue in powder); WFF - With foliar fertilization; WoFF - Without foliar fertilization Figure 1. Leaf area (A) and root volume (B) of papaya seedlings as a function of different substrates and foliar fertilization 
The contents of all macronutrients (Table 4 ) in the shoots of papaya seedlings were significantly $(\mathrm{p}<0.01)$ influenced by the substrates, whereas the foliar fertilization affected only the content of sulfur $(p<0.01)$. Probably, the absence of significant effect for the nutrients $\mathrm{N}, \mathrm{P}, \mathrm{K}, \mathrm{Ca}$ and $\mathrm{Mg}$ is associated with the supply of these elements to the papaya seedlings, since the studied organic substrates are not inert and have these nutrients in their compositions (Table 1).

The substrate composed of $\mathrm{EH}$ promoted increment in the $S$ content in the shoot dry matter of papaya seedlings (Table 4), with superiority of $255.55 \%$ compared with the lowest mean observed in MCR. The mean contents of $S$ in the shoots of papaya seedlings (Figure 2) differed statistically between the substrates CRRH, CRP, CRSD and MCR, which showed lower means.

The foliar fertilization increased at least $120 \%$ and at most $372.22 \%$ the S content in the shoots of 'Formosa' papaya

Table 4. Contents of the macronutrients nitrogen $(\mathrm{N})$, phosphorus $(\mathrm{P})$, potassium $(\mathrm{K})$, calcium $(\mathrm{Ca})$, magnesium $(\mathrm{Mg})$ and sulfur $(\mathrm{S})$ in the shoots of papaya seedlings, as a function of substrates and foliar fertilization

\begin{tabular}{lcccccc}
\hline \multirow{2}{*}{$\begin{array}{c}\text { Source } \\
\text { of variation }\end{array}$} & $\mathbf{N}$ & $\mathbf{P}$ & $\mathbf{K}$ & $\mathbf{C a}$ & $\mathbf{M g}$ & $\mathbf{S}$ \\
\cline { 2 - 7 } S (F value) & $0.58^{\text {ns }}$ & $0.10^{\text {ns }}$ & $1.23^{\text {ns }}$ & $1.56^{\text {ns }}$ & $0.64^{\text {ns }}$ & $100.68^{\text {** }}$ \\
FF (F value) & $0.05^{\text {ns }}$ & $0.06^{\text {ns }}$ & $0.06^{\text {ns }}$ & $0.03^{\text {ns }}$ & $0.04^{\text {ns }}$ & $240.45^{\star \star}$ \\
SxFF (F value) & $0.69^{\text {ns }}$ & $0.91^{\text {ns }}$ & $0.62^{\text {ns }}$ & $0.45^{\text {ns }}$ & $0.01^{\text {ns }}$ & $96.28^{\star \star}$ \\
CV (\%) & 26.49 & 70.91 & 29.90 & 34.78 & 8.49 & 7.72 \\
\hline EH & $3.93 \mathrm{a}$ & $0.87 \mathrm{a}$ & $3.32 \mathrm{a}$ & $0.95 \mathrm{a}$ & $0.62 \mathrm{a}$ & $0.46 \mathrm{a}$ \\
CRRH & $3.25 \mathrm{a}$ & $0.71 \mathrm{a}$ & $3.20 \mathrm{a}$ & $0.93 \mathrm{a}$ & $0.63 \mathrm{a}$ & $0.38 \mathrm{~b}$ \\
CRP & $3.85 \mathrm{a}$ & $0.82 \mathrm{a}$ & $4.12 \mathrm{a}$ & $1.20 \mathrm{a}$ & $0.64 \mathrm{a}$ & $0.48 \mathrm{ab}$ \\
CRSD & $4.05 \mathrm{a}$ & $0.70 \mathrm{a}$ & $2.96 \mathrm{a}$ & $0.74 \mathrm{a}$ & $0.60 \mathrm{a}$ & $0.30 \mathrm{C}$ \\
MCR & $3.70 \mathrm{a}$ & $0.78 \mathrm{a}$ & $3.12 \mathrm{a}$ & $1.09 \mathrm{a}$ & $0.64 \mathrm{a}$ & $0.18 \mathrm{~d}$ \\
LSD & 1.72 & 0.95 & 1.73 & 0.59 & 0.09 & 0.04 \\
WFF & $3.71 \mathrm{a}$ & $0.75 \mathrm{a}$ & $3.29 \mathrm{a}$ & $0.99 \mathrm{a}$ & $0.63 \mathrm{a}$ & $0.27 \mathrm{~b}$ \\
WoFF & $3.80 \mathrm{a}$ & $0.80 \mathrm{a}$ & $3.39 \mathrm{a}$ & $0.97 \mathrm{a}$ & $0.62 \mathrm{a}$ & $0.42 \mathrm{a}$ \\
LSD & 0.75 & 0.42 & 0.76 & 0.26 & 0.04 & 0.02 \\
\hline
\end{tabular}

LSD - Least significant difference; CV - Coefficient of variation; S - Substrates; EH - Earthworm humus (commercial substrate); CRRH - Carnauba residue + rice husk; CRP - Carnauba residue in powder; CRSD - Carnauba residue semi-decomposed; MCR - Mixture of carnauba residue (carnauba residue with rice husk + carnauba residue semi-decomposed + carnauba residue in powder); FF - Leaf area; WoFF - Without foliar fertilization; WFF - With foliar fertilization; ns - No significant; * Significant at 0.05 probability level; **Significant at 0.01 probability level; Means followed by the same letter in each column do not differ by Tukey test at 0.05 probability level

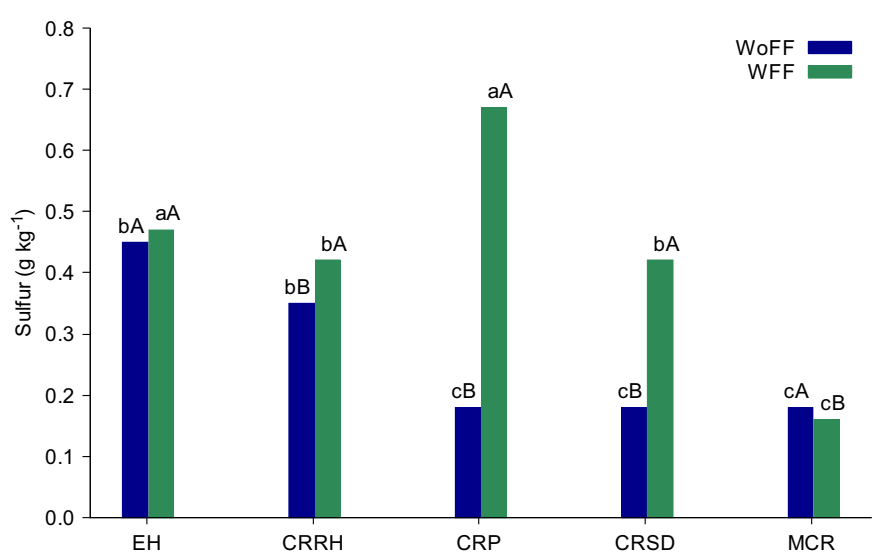

Bars with the same lower and uppercase letters do not differ with respect to substrate composition and foliar fertilization by Tukey test at 0.05 probability levels. EH - Earthworm humus (commercial substrate); $\mathrm{CRRH}$ - Carnauba residue + rice husk; CRP - Carnauba residue in powder; CRSD - Carnauba residue semi-decomposed; MCR - Mixture of carnauba residue (carnauba residue with rice husk + carnauba residue semi-decomposed + carnauba residue in powder); WFF - With foliar fertilization; WoFF - Without foliar fertilization

Figure 2. Sulfur content in the shoots of papaya seedlings as a function of different substrates and foliar fertilization seedlings (Figure 2), which may have occurred because of the low content of this nutrient in the substrates, especially in those that contain carnauba residue, since in the substrate with EH the means did not differ statistically when the foliar fertilizer was applied.

Considering that both sulfur and nitrogen perform similar functions and directly interfere with processes that are part of plant physiology, from ionic absorption to DNA and RNA composition (Pessarakli, 2014), the application of foliar fertilizer is necessary because $S$ is mostly supplied indirectly, especially when added to the soil, through fertilizers that contain this element, because sulfate fertilization is not a common practice.

\section{Conclusions}

1. The agroindustrial residue of carnauba wax semidecomposed (CRSD) can be used as substrate in the production of good quality seedlings of 'Formosa' papaya.

2. Foliar fertilization increases the quality of papaya seedlings, leading to increments in leaf area, root volume and sulfur content in the leaves, thus becoming a necessary practice.

\section{Literature Cited}

Albano, F. G.; Marques, A. S.; Cavalcante, Í. H. L. Substrato alternativo para produção de mudas de mamoeiro formosa (cv. Caliman). Científica, v.42, p.388-395, 2014. http://dx.doi. org/10.15361/1984-5529.2014v42n4p388-395

Almeida, J. P. N. A.; Dantas, L. L. G. R.; Pereira, E. C.; Tosta, M. S.; Medeiros, P. V. Q. Composição de substratos alternativos com capítulo de girassol na produção de mudas de mamoeiro. Revista Verde de Agroecologia e Desenvolvimento Sustentável, v.6, p.174-181, 2011.

Araújo, W. B. M.; Alencar, R. D.; Mendonça, V.; Medeiros, E. V.; Andrade, R. C.; Araújo, R. R. Esterco caprino na composição de substratos para formação de mudas de mamoeiro. Ciência e Agrotecnologia, v.34, p.68-73, 2010. http://dx.doi.org/10.1590/ S1413-70542010000100008

Ayers, R. S.; Westcot, D. W. Qualidade da água na agricultura. Campina Grande: UFPB. 1999. 153p. Estudos FAO: Irrigação e Drenagem, 29

Boodt, M. de; Verdonck, O. The physical properties of the substrates in horticulture. Acta Horticulturae, v.26, p.37-44, 1972. http:// dx.doi.org/10.17660/ActaHortic.1972.26.5

Cavalcante, M. Z. B.; Amaral, G. C.; Cavalcante, Í. H. L.; Lima, M. P. D. Alternative substrates for production of Heliconia psittacorum L. seedlings under shade and open field conditions. African Journal of Biotechnology, v.10, p.272-277, 2011.

Costa, E.; Leal, P. A. M.; Santos, L. C. R.; Vieira, L. C. R. Crescimento de mudas de mamoeiro conduzidas em diferentes ambientes protegidos, recipientes e substratos na região de Aquidauana, estado do Mato Grosso do Sul. Acta Scientiarum Agronomy, v.32, p.463-470, 2010. http://dx.doi.org/10.4025/actasciagron. v32i3.4449

Dickson, A.; Leaf, A. L.; Hosner, J. F. Quality appraisal of white spruce and white pine seedling stock in nurseries. The Forestry Chronicle, v.36, p.10-13, 1960. http://dx.doi.org/10.5558/tfc36010-1 
El-Hendawy, S.; Hu, Y.; Schimidhalter, U. Growth, ion content, gas exchange, and water relations of wheat genotypes differing in salt tolerances. Australian Journal of Agricultural Research, v.56, p.123-134, 2005. http://dx.doi.org/10.1071/AR04019

Falcão Neto, R.; Cavalcante, Í. H. L.; Rocha, L. F.; Costa, L. S.; Albano, F. G.; Cavalcante, M. Z. B. Estado nutricional de mudas de castanha-do-gurguéia em função de adubação nitrogenada e tratamento de substrato. Magistra, v.26, p.28-37, 2014.

IBGE - Instituto Brasileiro de Geografia e Estatística. Levantamento sistemático da produção agrícola, 2012. <http://www.ibge.gov. br/>. 18 Jan. 2015.

Kämpf, A. N. Seleção de materiais para uso como substrato. In: Kämpf, A. N.; Fermino, M. H. (ed.) Substrato para plantas: A base da produção vegetal em recipientes. Porto Alegre: Gênesis, 2000. p.139-145.

Lima, R. L. S.; Siqueira, D. L.; Weber, O. B.; Cazetta, J. O. Comprimento de estacas e parte do ramo na formação de mudas de aceroleira. Revista Brasileira de Fruticultura, v.28, p.83-86, 2006. http:// dx.doi.org/10.1590/S0100-29452006000100024

Malavolta, E.; Vitti, G. C.; Oliveira, S. A. Avaliação do estado nutricional das plantas: Princípios e aplicações. 2.ed. Piracicaba: Potafos, 1997.319p.

MAPA - Ministério da Agricultura Pecuária e Abastecimento. Instituição normativa. DAS nº 17 , de 21 de maio de 2007. Diário Oficial da República Federativa do Brasil. Brasília, 24 de maio de 2007, seção 1, 8p.

Matos, R. R. S. S.; Cavalcante, Í. H. L.; Silva Júnior, G. B.; Albano, F. G.; Cunha M. S.; Cavalcante, M. Z. B. Foliar spray of humic substances on seedling production of watermelon cv. Crimson Sweet. Journal of Agronomy, v.11, p.60-64, 2012. http://dx.doi. org/10.3923/ja.2012.60.64

Matos, R. R. S. S.; Silva Júnior, G. B.; Marques, A. S. ; Monteiro, M. L.; Cavalcante, Í. H. L.; Osajima, J. A. New organic substrates and boron fertilizing for production of yellow passion fruit seedlings. Archives of Agronomy and Soil Science, v.62, p.445-455, 2016. http://dx.doi.org/10.1080/03650340.2015.1050000

Melo Júnior, J. C. F.; Lima, A. M. N.; Teixeira, M. V.; Conceição, G. C.; Santos, L. R. Depleção de água no substrato e doses de fertilizante Osmocote na formação de mudas de mamoeiro. Comunicata Scientiae, v.5, p.499-508, 2014.
Menegazzo, M. L.; Oliveira, A. C.; Silva, E. A. Adubação nitrogenada na produção de mudas de mamoeiro. Revista Agrarian, v.4, p.189-196, 2011.

Pessarakli, M. Handbook of plant and crop physiology. 3.ed. New York: Marcel Dekker, 2014. 1031p.

Saraiva, K. R.; Nascimento, R. S.; Sales, F. A. L.; Araújo, H. F.; Fernandes, C. N. V.; Lima, A. D. Produção de mudas de mamoeiro sob doses de adubação fosfatada utilizando como fonte superfosfato simples. Revista Brasileira de Agricultura Irrigada, v.5, p.376-383, 2011. http://dx.doi.org/10.7127/rbai.v5n400065

Schmitz, J. A. K.; Souza, P. V. D.; Kämpf, A. N. Propriedades químicas e físicas de substratos de origem mineral e orgânica para o cultivo de mudas em recipientes. Ciência Rural, v.32, p.937-944, 2002. http://dx.doi.org/10.1590/S0103-84782002000600005

Silva, A. K.; Costa, E.; Santos, E. L. L.; Benett, K. S. S.; Benett, C. G. S. Produção de mudas de mamoeiro 'formosa' sob efeito de tela termorrefletora e substratos. Revista Brasileira de Ciências Agrárias, v.8, p.42-48, 2013. http://dx.doi.org/10.5039/agraria.v8ila1996

Silva Júnior, J. V.; Cavalcante, M. Z. B.; Brito, L. P. S.; Avelino, R. C.; Cavalcante, Í. H. L. Aproveitamento de materiais alternativos na produção de mudas de tomateiro sob adubação foliar. Revista Ciência Agronômica, v.45, p.528-536, 2014. http://dx.doi. org/10.1590/S1806-66902014000300013

Steffen, G. P. K.; Antoniolli, Z. I.; Steffen, R. B.; Schiedeck, G. Utilização do vermicomposto como substrato na produção de Eucalyptus grandis e Corymbia citriodora. Pesquisa Florestal Brasileira, v.31, p.75-82, 2011. http://dx.doi.org/10.4336/2011.pfb.31.66.75

Verdonck, O.; Gabriels, R. Substrate requirements for plants. Acta Horticulturae, v.221, p.19-23, 1988. http://dx.doi.org/10.17660/ ActaHortic.1988.221.1

Weber, O. B.; Correia, D.; Silveira, M. D.; Crisóstomo, L. A.; Oliveira, E. D.; Sá, E. G. Efeito da bactéria diazotrófica em mudas micropropagadas de abacaxizeiros Cayenne Champac em diferentes substratos. Pesquisa Agropecuária Brasileira, v.38, 689696, 2003. http://dx.doi.org/10.1590/S0100-204X2003000600004

Yamanishi, O. K.; Fagundes, G. R.; Machado Filho, J. A.; Valone, G. V. Efeito de diferentes substratos e duas formas de adubação na produção de mudas de mamoeiro. Revista Brasileira de Fruticultura, v.26, p.276-279, 2004. http://dx.doi.org/10.1590/ S0100-29452004000200023 